Received 15.06 .2015

Reviewed 03.08 .2015

Accepted $\quad 06.08 .2015$

A - study design

B - data collection

C - statistical analysis

D - data interpretation

$\mathbf{E}$ - manuscript preparation

F - literature search

\section{Multicriteria flood mitigation in the Imotsko-Bekijsko Polje (Croatia, Bosnia and Herzegovina)}

Igor LJUBENKOV ${ }^{\mathrm{ABCDEF}}$

Water Development Ltd., Split, Croatia, e-mail: info@waterdevelopment.hr

For citation: Ljubenkov I. 2015. Multicriteria flood mitigation in the Imotsko-Bekijsko Polje (Croatia, Bosnia and Herzegovina). Journal of Water and Land Development. No. 26 p. 73-81.

\begin{abstract}
Imotsko-Bekijsko Polje has an area of 9500 ha and is one of the biggest karst fields (polje) in the Dinaric Mountains, extending over the territory of two states: Croatia and Bosnia and Herzegovina. Many hydraulic structures (reservoirs, retentions, tunnels, etc.) have been built since the middle of $20^{\text {th }}$ century in order to protect polje against floods. Therefore, the security from flooding has increased substantially. However, there is still periodical flooding in the southeastern lowest part of the polje. The largest flood in recent times was in January 2010 , when 2676 ha (28\% of the area) was flooded. The polje is a typical karst with very complex hydrological and hydrogeological relations. In this paper two hydrological stations, Nuga at the lowest part and Kamenmost in the central part of the polje with respectable hydrological series, are statistically analysed. In particular, the efficiency of existing hydraulic structures for flood mitigation is estimated. The research points out that floods in Imotsko-Bekijsko Polje are largely influenced by water management objects (reservoir, retention, tunnel) and only indirectly by precipitation.
\end{abstract}

Key words: flood, Imotsko-Bekijsko Polje, karst polje, statistical test

\section{INTRODUCTION}

Dinaric karst is an extent, $800 \mathrm{~km}$ long and up to $150 \mathrm{~km}$ wide area of karst, which extends over majority of the Dinaric Mountains on the Balkan peninsula in SE Europe and through the western and southern part of Croatia (regions Istria, Kvarner, Lika and Dalmatia) and the majority of Bosnia and Herzegovina (Fig. 1) [BoNACCI 1987; MiHEVC et al. 2010].

The polje in the karst area can be defined as an extensive depression in carbonate massif, with fertile soil and relatively mild slope. Karst fields usually have numerous hydrological and hydrogeological forms such as permanent and temporary springs, streams, ponors, estavelles, etc. with a very complex and variable hydrological relationships [BONACCI 1987; 2004; BONACCI, LJUBENKOV 2006; KRESIC 2013; MiJATOVIĆ 1988; SACKL et al. 2014].

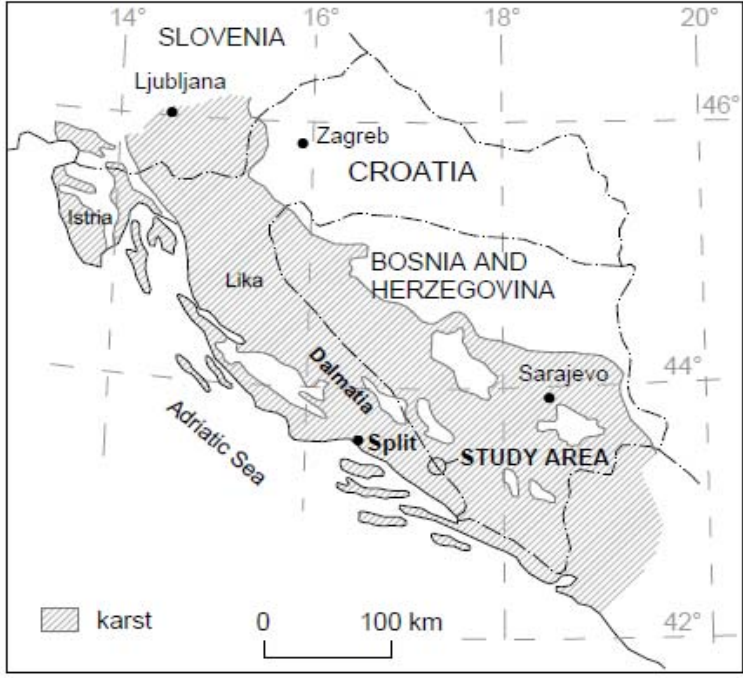

Fig. 1. Map of the Dinaric karst; source: own elaboration 
In the Dinaric karst, fields are restricted areas with the most favourable conditions for agriculture and life. The majority of those fields are elongated in one direction (NW-SE), surrounded by bare and sometimes inaccessible rocky terrain. Although relatively small in area, these Dinaric fields have enormous social and economic role. They have always been used for agriculture, and partly for animal husbandry.

In Dalmatia, southern Croatian region, there are more than one hundred karst poljes with area larger than 10 ha. Eleven of them has an area of more than 1000 ha and the largest is Imotsko-Bekijsko Polje (9 500 ha). Almost all of them are subject to occasional flooding in the cold and wet season (October to April), although some of them are meliorated. SCHWARZ [2013] summarised the potential flooding situation for 57 poljes in Bosnia and Herzegovina $(\mathrm{B} \& \mathrm{H})$, including Imotsko-Bekijsko Polje. His approach has been based on elevation model but he also took into account flood documentation, historical maps, etc.

Since floods make heavy damage, especially in agriculture, man has always exercised a number of interventions in poljes and their catchment in order to improve the hydrological regime i.e. to reduce the spatial extent and duration of floods. This problem is interesting also from the scientific point of view. For example, BONACCI [1987] analysed the impact of hydraulic structures on flood control in Vrgorsko Polje (Croatia). ZHANG et al. [2014] applied t and F test and determined abrupt streamflow changes of the East River in China influenced by both water reservoir construction and precipitation changes.

The first land-improvement works in the area of Imotsko-Bekijsko Polje took place in the 19th century and involved increasing the capacity of ponors and

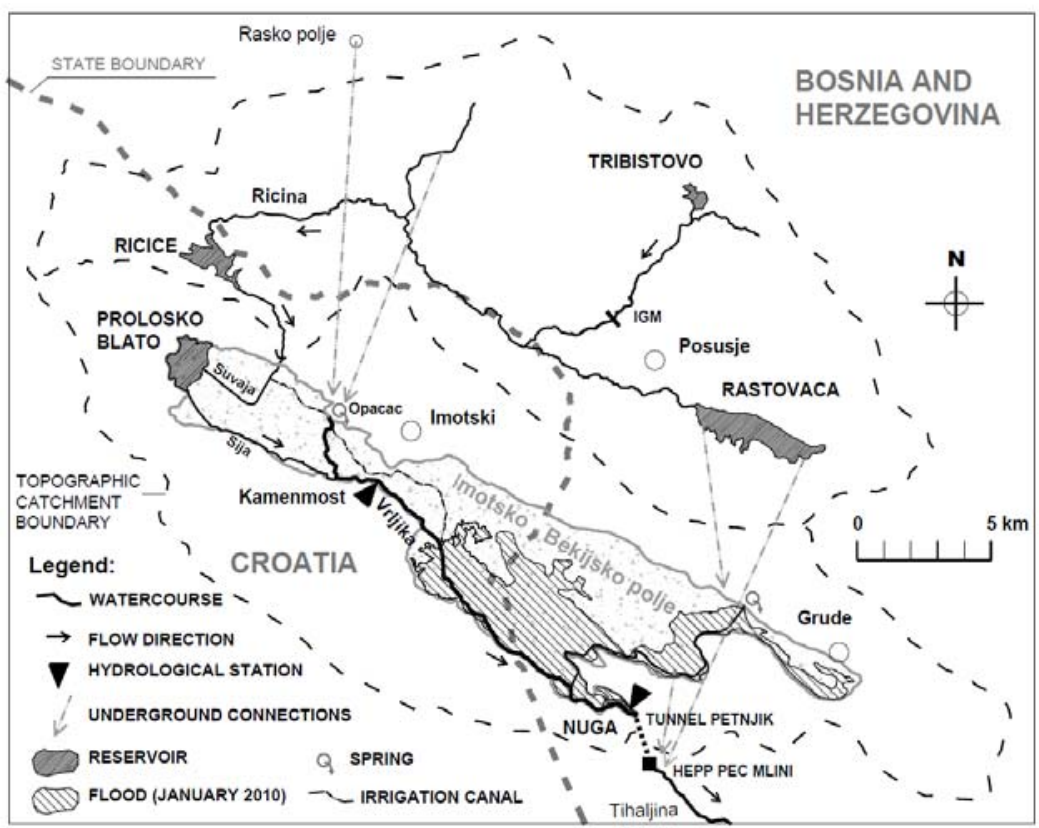

Fig. 2. Map of catchment area of the Imotsko-Bekijsko Polje; source: own elaboration river regulation. However, intensive flood control and construction of appropriate facilities (reservoirs, retention reservoirs, tunnels, dams, canals and pumping stations) began in mid-20th century, after which the general state of the Imotsko-Bekijsko Polje has been improved. The aim of this paper is to describe the regime of high water in Imotsko-Bekijsko Polje and to give an overview of the role of the existing facilities in flood mitigation.

\section{HYDROLOGICAL REGIME}

\section{STUDY AREA}

Imotsko-Bekijsko, the largest Dalmatian karst polje has an area of 9500 hectares (i.e. $95 \mathrm{~km}^{2}$ ), of which 4400 hectares is located in the Republic of Croatia, and the remaining 5100 hectares in neighbouring Bosnia and Herzegovina (Fig. 2). The higher western part of the polje (altitude between 254 and $280 \mathrm{~m}$ a.s.1.) belongs to Croatia while the eastern lower part (altitude between 249 and $266 \mathrm{~m}$ a.s.1.) belongs to $\mathrm{B} \& \mathrm{H}$. The topographic catchment of the polje covers $325 \mathrm{~km}^{2}$. Besides from direct catchment, ImotskoBekijsko Polje receives surface water from the Suvaja (Ricina) River on the north-western edge of the polje (Fig. 2). The Ricina collects water in the area of Posusje and brings it to the reservoir Ricice. The topographic catchment of the Ricina is about $300 \mathrm{~km}^{2}$, located at higher areas between 300 and $1300 \mathrm{~m}$ a.s.l. Obviously, it is an indirect catchment of the polje. Downstream the reservoir Ricice this watercourse is called the Suvaja. It flows along a $3.8 \mathrm{~km}$ canyon through the polje and finally it finishes in Prolosko blato. The polje is also fed by waters from numerous karst springs located on the northern edge of the polje (Opacac, Krenica, Slavic, Grudsko vrilo etc.). So, water comes to polje from the higher area of Posusje i.e. an indirect part of the catchment by surface flow (the Suvaja) as well as from karst underground (springs).

Climate of this area is influenced by the Mediterranean Sea from the west and by the continental hinterland. Average annual precipitation at the meteorological station Imotski $\left(43^{\circ} 27^{\prime} \mathrm{N}, 1^{\circ} 13^{\prime}\right.$ E, $435 \mathrm{~m}$ a.s.1.) was $1280 \mathrm{~mm}$ in the period 1957-2013. Imotski is the biggest place in this area. The minimum annual precipitation was $746 \mathrm{~mm}$ (year 1983) while the maximum was $1905 \mathrm{~mm}$ (year 2010). The summer months could be without precipitations. The highest precipitations are in the autumn-winter period. The rainiest month is November with an average precipitation of $189 \mathrm{~mm}$. The average annual temperature is 
$13.8^{\circ} \mathrm{C}$. The coldest month is January with $5.0^{\circ} \mathrm{C}$ and the hottest is July with $24.0^{\circ} \mathrm{C}$.

The entire catchment area of the polje has very complex hydrogeological relations [BONACCI et al. 2013]. Certainly, topographic (morphological) and hydrogeological catchment boundary of Imotsko-Bekijsko Polje are different. The real boundaries of the catchment are mostly underground and rarely topographic.

The catchment area of the polje is built of Cretaceous limestone and dolomite, sandstone, shale and conglomerate, Miocene marl and clay limestone and Quaternary alluvial and talus deposits. Carbonate deposits are very tectonically fractured and highly karstified and represent all types of karst phenomena.

Quaternary sediments (Q) prevail in the field with alluvial (al) sandstones, clay sands and gravels and their mixtures (limestone debris with clay and red soil). The thickness of these layers varies and reaches more than $130 \mathrm{~m}$.

The only permanent watercourse, the Vrljika River of a length of about $18 \mathrm{~km}$, flows from its source Opacac to the lowest area Nuga, meandering through the polje. Besides, the polje is cut with numerous drainage and irrigation canals.

Since, the Imotsko-Bekijsko Polje and associated water management facilities are placed in the territory of two countries, it is so-called "intersected" system. It is actually a natural and technical unit but separated in two parts from administrative point of view (Fig. 2). Also, Imotsko-Bekijsko Polje is higher and upstream area for a few lower downstream poljes: Ljubuško Polje (B\&H), Rastok (B\&H and Croatia) and Vrgorsko Polje (Croatia), located between 30 and $75 \mathrm{~m}$ a.s.l., so it has an important hydrological influence on them.

Under natural conditions, Imotsko-Bekijsko is drained only through ponors located in southern edge of the polje (ponors Nuga, Kongora, Prispa etc.). There was a flood when capacity of ponors was insufficient. The area most vulnerable to flooding was the southern part of the field (Nuga), which is the lowest one (249 $\mathrm{m}$ a.s.1.), so all surface flow runs towards it.

\section{FLOOD CONTROL OBJECTS}

Tunnel Petnjik is the first built, and also the most important object for flood mitigation in the Imotsko-Bekijsko Polje (Fig. 2). Construction of the tunnel began before World War II, and was completed and put into operation in 1951 . The capacity of the tunnel is about $40 \mathrm{~m}^{3} \cdot \mathrm{s}^{-1}$. The tunnel serves for the evacuation of water from Nuga to the lower area i.e. watercourse Tihaljina, which continues its course under the name Mlada and Trebizat until its inflow into the Neretva River. Further on, the Neretva River flows into the Adriatic Sea.

Then, two retention reservoirs Rastovaca on the Ricina and Prološko blato on the western edge of the polje were completed in 1956. Furthermore, three reservoirs were built, Ricice in 1989, Tribistovo (1990) and IGM (1994), situated in the "indirect" part of the polje's catchment. The construction of major facilities in this water management system ended in 2004 when HEPP Pec Mlini started to work. Its supply tunnel (capacity $30 \mathrm{~m}^{3} \cdot \mathrm{s}^{-1}$ ) was set parallel to the tunnel Petnjik. Therefore, drainage of the lowest area of the polje is nowadays achieved via tunnel Petnjik and HEPP's tunnel. The polje is flooded generally in wet periods but flooding depends also on human activity i.e. on the operation of hydraulic structures. For example, in the flood risk period along the Tihaljina, tunnels are partially or fully closed. Therefore, it increases water level in the retention reservoir Nuga contributing flood to the lowest part of the polje.

Reservoir Ricice was planned as a multi-purpose object for flood control, irrigation and water supply. It is the biggest reservoir in this area. Unfortunately, it did not meet expectations in terms of providing sufficient quantities of water for irrigation of the polje. It was designed to a volume of 35.2 million $\mathrm{m}^{3}$, but it has never been completely filled. This is due to leaching losses from the reservoir itself, but also to reduced inflows from the catchment Ricina compared with the project documentation. However, after the construction of reservoir Ricice (1989), high surface water waves that reach Imotsko-Bekijsko Polje have been reduced and thus polje's flood protection has been improved.

Downstream the reservoir Ricice, surface water flows through the Suvaja riverbed, whose discharge largely depends on the releases from the reservoir, except in the extreme flood situations. Now, this watercourse is mainly used for releasing water for irrigation. Through the Suvaja riverbed, surface waters enter the polje in Prolozac where they are partially diverted in irrigation canal while most of water continues its flow to retention reservoir Prolosko blato constructed in 1956. Water from this reservoir is discharged into Sija canal through sluice gate. Canal is 7.2 kilometres long and flows into the Vrljika River. After the construction of the Ricica dam, Sija canal is mostly empty.

In the previous period, about $120 \mathrm{~km}$ of drainage canals were constructed in the polje apart from mentioned above facilities. Also, the most important watercourse the Vrljika was regulated. Therefore, drainage network of polje is solid though it requires intensive maintenance (cutting of vegetation, removal of debris etc.).

\section{HIGH WATER REGIME}

Hydrological conditions in the Imotsko-Bekijsko Polje are monitored in six locations: Prolozac (at the Suvaja and irrigation canal), Opacac (at the Vrljika and irrigation canal), Kamenmost (at the Vrljika) and the Sija (the homonymous waterourse) in Croatia and Grudsko vrilo and Nuga in B\&H. Hydrological stations at Suvaja and Opacac have relatively short 
measurement series (less than 20 years), so they are not acceptable for statistical analysis. According to engineering practice, hydrological time series should be at least 30 years long to apply statistical methods [Prohaska 2003; RAGHUNATH 2006]. Furthermore, gauging station Sija has sufficiently long measurements but it is directly influenced by retention reservoir Prolosko blato, therefore, it was not considered in this paper. Station Grudsko vrilo has a relatively long series, but it could not register the highest flow rates. So it is not useful for flood analysis. The remaining two stations, Kamenmost and Nuga have a relatively long series ( $N=56$ and 72, respectively) so the appropriate statistical analysis could be applied to them. They are also the most important stations in this area from the hydrological point of view. Kamenmost closes the whole indirect part of the catchment as well as western part of the polje and covers the majority of water that causes flooding. Nuga is in the lowest part of the area and is critical for floods. The methods used in this work: $t$-test and $F$-test are widely used, commonly accepted and can be applied to any other similar sequences. These statistical tests are given in many papers [BONACCI 1987; MIRZA 2004; ZHANG et al. 2014]. BONACCI [1987] used the same approach for Vrgorsko Polje analysis.

The Vrljika River flows are detected at the hydrologic station Kamenmost, which has been in operation since the end of the 19th century. But the station in this long period was shifted and reconstructed several times. Limnigraph was installed in 1956, since then it registered discharges. It measures flow from the entire upstream catchment except a relatively small amounts of water that flows through the main irrigation canal located approximately parallel to the Vrljika, which is used only in the vegetation period (from April to September). Fig. 3a shows maximum discharges, mean high and monthly mean discharges in Kamenmost in the operation period 1957-2013. The highest flow of $99.4 \mathrm{~m}^{3} \cdot \mathrm{s}^{-1}$ was recorded in December 1959 . Mean monthly flows were less than $20 \mathrm{~m}^{3} \cdot \mathrm{s}^{-1}$ and could not cause floods. Discharges greater than $50-60 \mathrm{~m}^{3} \cdot \mathrm{s}^{-1}$ can cause flood locally along the Vrljika as well as in the lowest area of Nuga. After the construction of Ricice retention reservoir, maximum discharges were reduced. Fig. 3b shows characteristic monthly flows in new conditions (period 1989-2013) that reflect the actual status. The maximum flow recorded in December 2004 was $65.5 \mathrm{~m}^{3} \cdot \mathrm{s}^{-1}$. Obviously, flood risk was reduced but floods are still possible. We can say that water flow in this profile after 1989 has two components - the artificial and the natural. Artificial one arises from the working regime of hydraulic structures such as the reservoir Ricice (1989) and Prolosko blato (1956), while the natural flow depends on the source Opacac and surface inflow in wet period. Detailed analysis of high water recorded in this gauging location is explained below.

Nuga gauging station is located in the retention reservoir of the same name in the lowest part of the
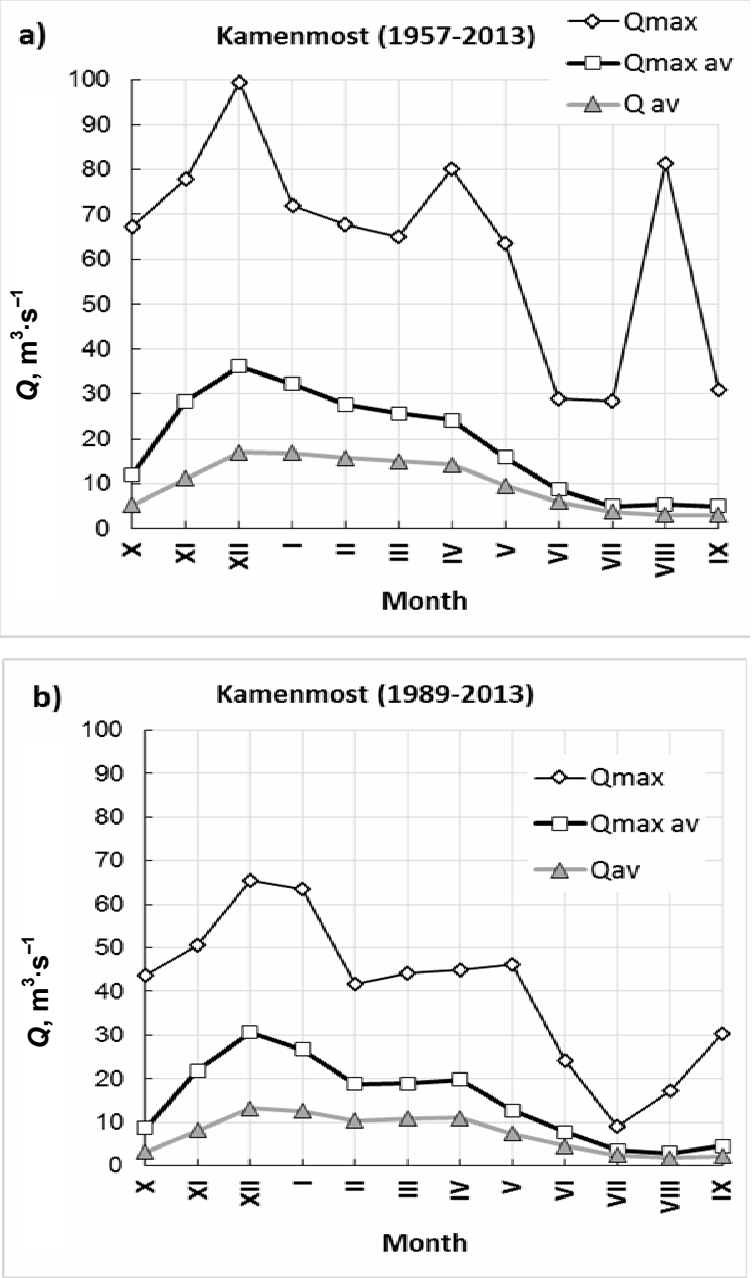

Fig. 3. Characteristic monthly discharges in Kamenmost: a) in the operation period, b) after Ricice reservoir; $Q \max =$ maximum recorded discharge, $Q$ maxav = mean maximum monthly discharge, $Q \mathrm{av}=$ mean monthly discharge; source: own study

polje, next to the entrance to the drainage tunnel and has a key role in flood monitoring. Water levels have been recorded since 1926 with interruptions in 1943, 1944, from 1946 to 1949, 1992, 1993, 1994 and from 2003 to 2005 . Detailed analysis of high water in this location is presented below.

Another gauging station in Bosnia and Herzegovina is Grudsko vrilo, located in springs of the same name. Water from this source flows to the retention reservoir Nuga by a drainage canal. The station began operation in 1961, with an interruption of work on several occasions. The highest flow rates in this profile can not be determined.

\section{RESULTS}

Before construction of the tunnel Petnjik (1951), the field was flooded almost every year. The largest recorded flood before construction of the tunnel was in winter 1934/1935 when the flood covered 5333 ha ( $56 \%$ of the field), and lasted approximately 6.5 months (Figs. 4, 5 and 6). In the following sub-period 


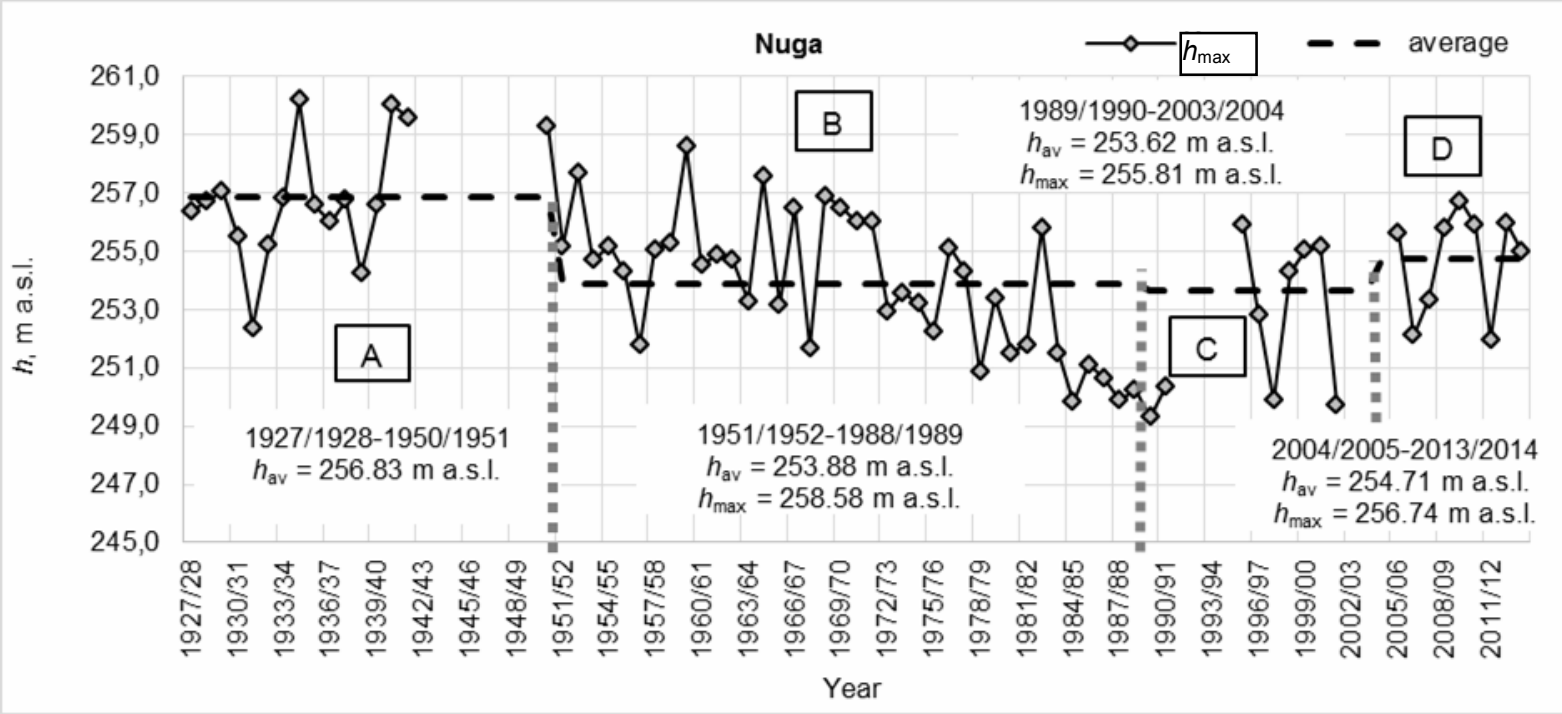

Fig. 4. Series of maximum annual water levels in Nuga; A: before tunnel Petnjik construction, B: after tunnel construction, C: after reservoir Ricice construction, D: present conditions i.e. after HEPP Pec Mlini construction; source: own study

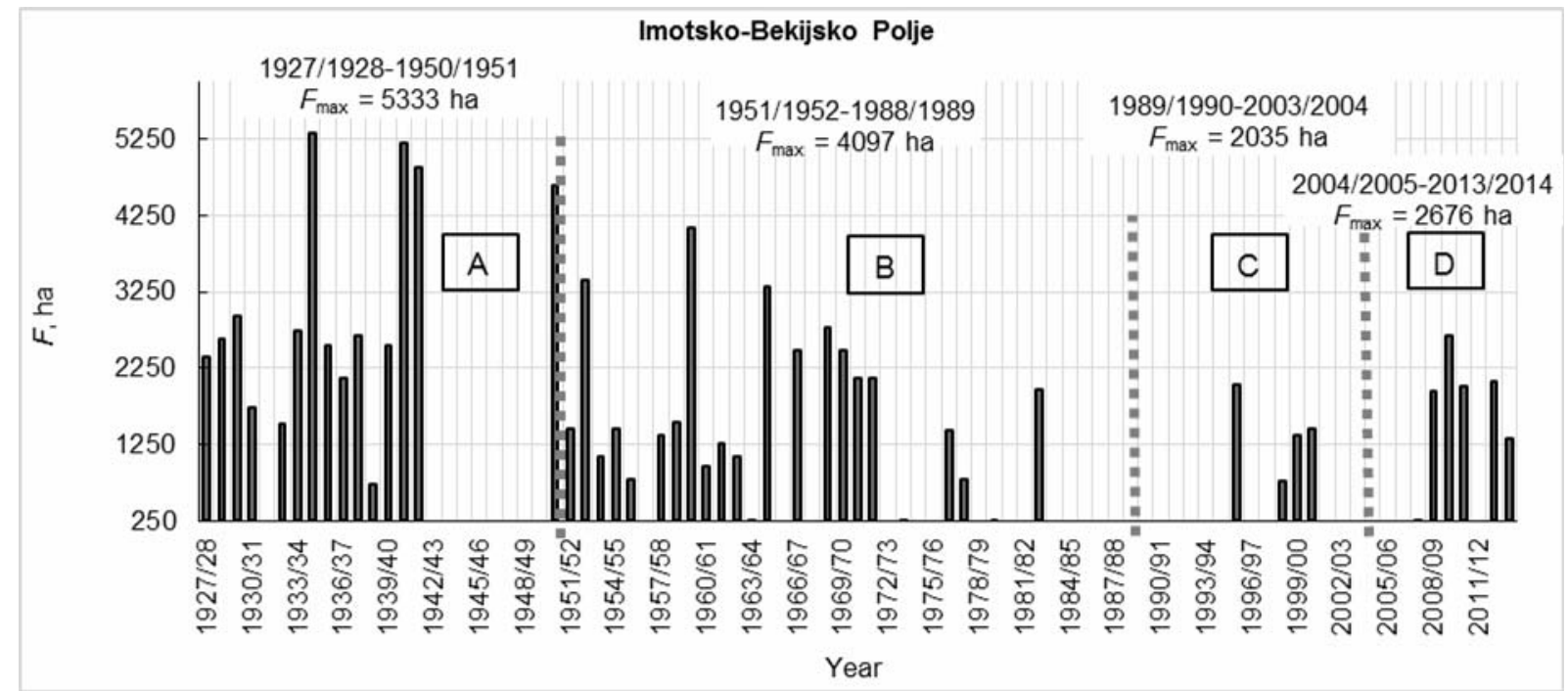

Fig. 5. Series of flooded area in the period 1927-2013; A-D as in Fig. 4; source: own study

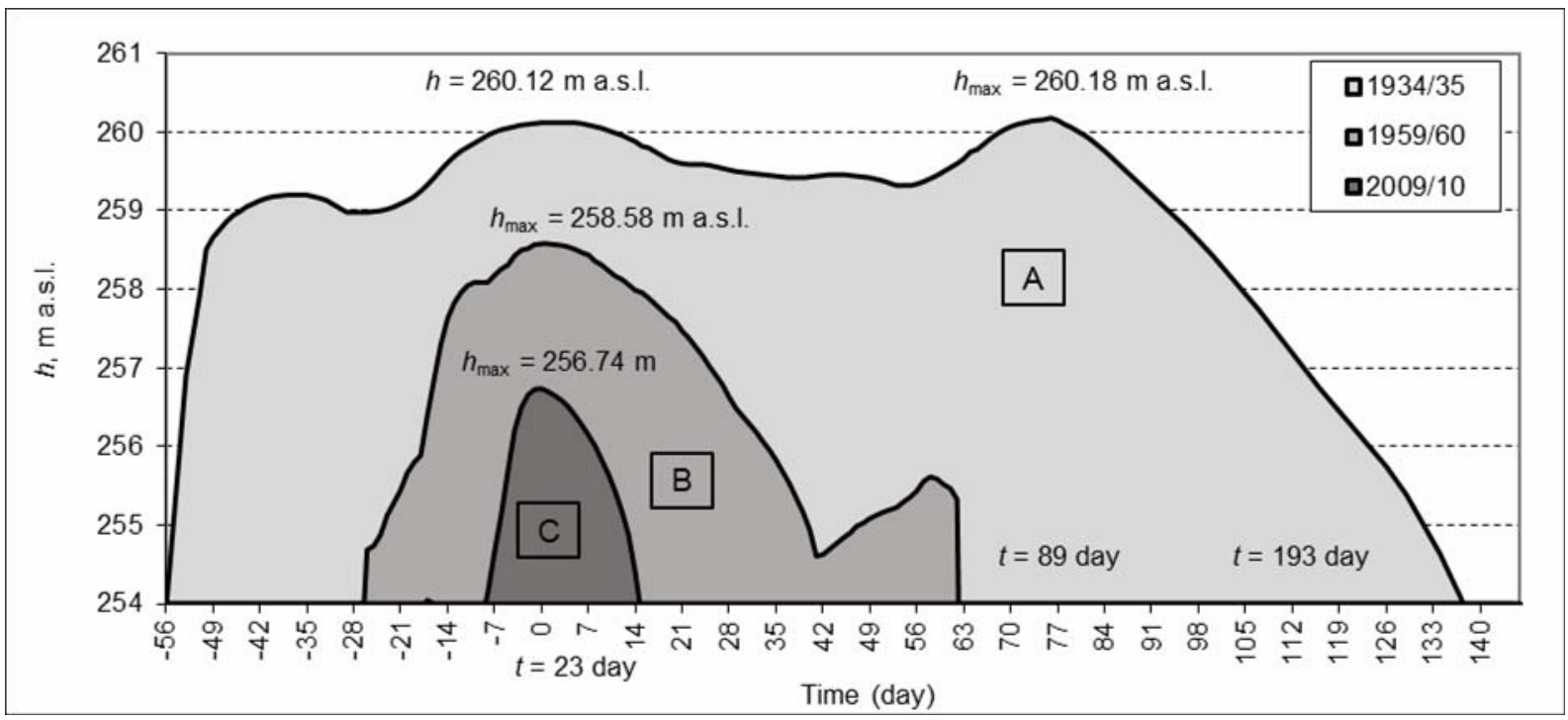

Fig. 6. Comparison of flood events in different periods; A: before tunnel Petnjik construction, B: after tunnel construction, C: present conditions i.e. after HEPP Pec Mlini construction; source: own study 
(from 1951 to 1989), after construction of the tunnel Petnjik but before construction of the Ricice retention reservoir, the largest flood was recorded in winter 1959/1960. Its maximum coverage was 4097 ha $(43 \%$ of the field), and total duration was 89 days. In the next period (1989/1990-2003/2004), after construction of the reservoir Ricica and before HEPP Pec Mlini, the maximum water elevation was $255.91 \mathrm{~m}$ a.s.1. registered in January 1996. Corresponding flooded area was 2035 ha. Later, after HEPP construction, the largest flood was in January 2010 with water table elevation of $256.74 \mathrm{~m}$ a.s.l. It flooded 2676 hectares ( $28 \%$ of the field), and the corresponding amount of water was $57 \cdot 10^{6} \mathrm{~m}^{3}$. The duration of the flood was only 23 days.

Fig. 5 shows the size of flooded areas in ha, that corresponds to maximum water elevation per hydrological years from $1927 / 1928$ to $2012 / 2013$. Unfortunately, there were interruptions in water observations but qualitative explanation of flood processes is achieved due to statistical analysis. Essential data for analysed periods are given in Tab. 1. Maximum water tables from different sub-periods are compared in Fig. 6. It is evident that floods are now mitigated i.e. flood extent and duration are reduced.

There was a significant $(\alpha=0.05)$ difference between mean water levels at station Nuga in two time series: $1927 / 1928-1951 / 1952$ and $1952 / 1953$ to $1988 / 1989$, i.e. before and after the construction of the tunnel Petnjik (Tab. 2). In this case statistical hypothesis $\mathrm{H}_{1}$ was accepted. Other periods did not show significant differences, so $\mathrm{H}_{0}$ hypothesis that the two
Table 1. Data on high water levels in Nuga in various periods

\begin{tabular}{|l|c|c|c|c|}
\hline \multicolumn{1}{|c|}{ Parameter } & $\begin{array}{c}1927- \\
1951\end{array}$ & $\begin{array}{c}1951- \\
1988\end{array}$ & $\begin{array}{c}1988- \\
2004\end{array}$ & $\begin{array}{c}2004- \\
2014\end{array}$ \\
\hline No. of data & 16 & 38 & 9 & 9 \\
\hline $\begin{array}{l}\text { Average high water } \\
\text { level, m a.s.l. }\end{array}$ & 256.83 & 253.88 & 253.62 & 254.71 \\
\hline $\begin{array}{l}\text { Maximum recorded } \\
\text { water level, m a.s.l. }\end{array}$ & 260.18 & 258.58 & 255.91 & 256.74 \\
\hline$h_{\text {max date }}$ & Mar 1935 & Dec 1959 & Jan 1996 & Jan 2010 \\
\hline Variance & 4.48 & 5.41 & 5.91 & 3.16 \\
\hline Skewness & -0.07 & -0.03 & -0.01 & -0.77 \\
\hline
\end{tabular}

Explanations: $h_{\max }=$ maximum recorded water level. Source: own study.

means are equal was accepted. For example, construction of Prolosko blato retention reservoir as well as HEPP Pec Mlini one did not statistically change high water mean (Tabs. 3, 4). The increase of high water mean is evident only for HEPP $(0.09 \mathrm{~m})$ while tunnel and retention reservoir decreased it. There were no significant differences of variances among these subperiods (Tab. 2, 34 ). Therefore, the variability of high water regime did not change despite the construction of hydrotechnical objects.

The two sub-periods were analysed in Kamenmost, before and after construction of Ricice retention resevoir (Fig. 7). Basic hydrologic data are presented in Table 5. Construction of this reservoir did not significantly change water peaks $\left(Q_{\max }\right)$ and its variability in hydrological series (Tab. 6). The largest water flow from the second sub-period $(1989 / 1990$ $2012 / 2013$ ) had a peak flow rate of $65.5 \mathrm{~m}^{3} \mathrm{~s}^{-1}$ (Dec 2004).

Table 2. Statistical tests for Nuga: the influence of tunnel Petnjik and Ricica reservoir

\begin{tabular}{|c|c|c|c|c|c|c|c|c|c|c|}
\hline \multicolumn{3}{|c|}{ Location: Nuga } & \multicolumn{8}{|c|}{ Parameter: Water table elevation } \\
\hline \multirow{2}{*}{ No. } & \multirow{2}{*}{ period } & \multirow{2}{*}{$N_{i}$} & \multirow{2}{*}{$\begin{array}{c}h_{\mathrm{av}} \\
\mathrm{m} \text { a.s.l. }\end{array}$} & \multirow{2}{*}{$s^{2}$} & \multicolumn{2}{|c|}{$h \quad \alpha=0.05$} & \multirow{2}{*}{ hypothesis } & \multicolumn{2}{|c|}{$\sigma^{2} \quad \alpha=0.05$} & \multirow{2}{*}{ hypothesis } \\
\hline & & & & & $t$-test & $t_{\text {crit }}$ & & $F$-test & $F_{\text {crit }}$ & \\
\hline 1 & $1927 / 1928-1950 / 1951$ & 16 & 256.83 & 4.48 & \multirow{2}{*}{2.27} & \multirow{2}{*}{2.01} & \multirow{2}{*}{$H_{1}$} & \multirow{2}{*}{0.83} & \multirow{2}{*}{0.45} & \multirow{2}{*}{$H_{0}$} \\
\hline \multirow{2}{*}{2} & $1951 / 1952-1988 / 1989$ & \multirow{2}{*}{38} & 253.88 & \multirow{2}{*}{5.41} & & & & & & \\
\hline & & & & & \multirow[t]{2}{*}{0.34} & \multirow[t]{2}{*}{2.01} & \multirow[t]{2}{*}{$H_{0}$} & \multirow[t]{2}{*}{0.87} & \multirow[t]{2}{*}{0.52} & \multirow[t]{2}{*}{$H_{0}$} \\
\hline 3 & 1989/1990-2012/2013 & 18 & 253.60 & 6.19 & & & & & & \\
\hline
\end{tabular}

Explanations: $N_{i}=$ No. of data, $h_{\mathrm{av}}=$ mean high water level, $s^{2}=$ high water level variance.

Source: own study.

Table 3. Statistical tests for Nuga: the influence of HEPP Pec-Mlini

\begin{tabular}{|c|c|c|c|c|c|c|c|c|c|c|}
\hline \multicolumn{3}{|c|}{ Location: Nuga } & \multicolumn{8}{|c|}{ Parameter: Water table elevation } \\
\hline \multirow{2}{*}{ No. } & \multirow{2}{*}{ period } & \multirow{2}{*}{$N_{i}$} & \multirow{2}{*}{$\begin{array}{c}h_{\mathrm{av}} \\
\text { m a.s.1. }\end{array}$} & \multirow{2}{*}{$s^{2}$} & \multicolumn{2}{|c|}{$h \alpha=0.05$} & \multirow{2}{*}{ hypothesis } & \multicolumn{2}{|c|}{$\sigma^{2} \quad \alpha=0.05$} & \multirow{2}{*}{ hypothesis } \\
\hline & & & & & $t$-test & $t_{\text {crit }}$ & & $F$-test & $F_{\text {crit }}$ & \\
\hline 1 & $1951 / 1952-2001 / 2002$ & 47 & 253.62 & 5.91 & \multirow{2}{*}{-1.17} & \multirow{2}{*}{2.01} & \multirow{2}{*}{$H_{0}$} & \multirow{2}{*}{1.87} & \multirow{2}{*}{3.01} & \multirow{2}{*}{$H_{0}$} \\
\hline 2 & $2005 / 2006-2012 / 2013$ & 9 & 254.71 & 3.16 & & & & & & \\
\hline
\end{tabular}

Explanations as in Tab. 2. Source: own study.

Table 4. Statistical tests for Nuga: the influence of Prolosko blato

\begin{tabular}{|c|c|c|c|c|c|c|c|c|c|c|}
\hline \multicolumn{3}{|c|}{ Location: Nuga } & \multicolumn{8}{|c|}{ Parameter: Water table elevation } \\
\hline \multirow{2}{*}{ No. } & \multirow{2}{*}{ period } & \multirow{2}{*}{$N_{i}$} & \multirow{2}{*}{$\begin{array}{c}h_{\mathrm{av}} \\
\text { m a.s.l. }\end{array}$} & \multirow{2}{*}{$s^{2}$} & \multicolumn{2}{|c|}{$h \alpha=0.05$} & \multirow{2}{*}{ hypothesis } & \multicolumn{2}{|c|}{$\sigma^{2} \quad \alpha=0.05$} & \multirow{2}{*}{ hypothesis } \\
\hline & & & & & $t$-test & $t_{\text {crit }}$ & & $F$-test & $F_{\text {crit }}$ & \\
\hline 1 & $1951 / 1952-1955 / 1956$ & 5 & 255.40 & 1.77 & \multirow{2}{*}{0.38} & \multirow{2}{*}{2.01} & \multirow{2}{*}{$H_{0}$} & \multirow{2}{*}{0.31} & \multirow{2}{*}{0.18} & \multirow{2}{*}{$H_{0}$} \\
\hline 2 & $1956 / 1957-2012 / 2013$ & 51 & 253.63 & 5.70 & & & & & & \\
\hline
\end{tabular}

Explanations as in Tab. 2. Source: own study. 


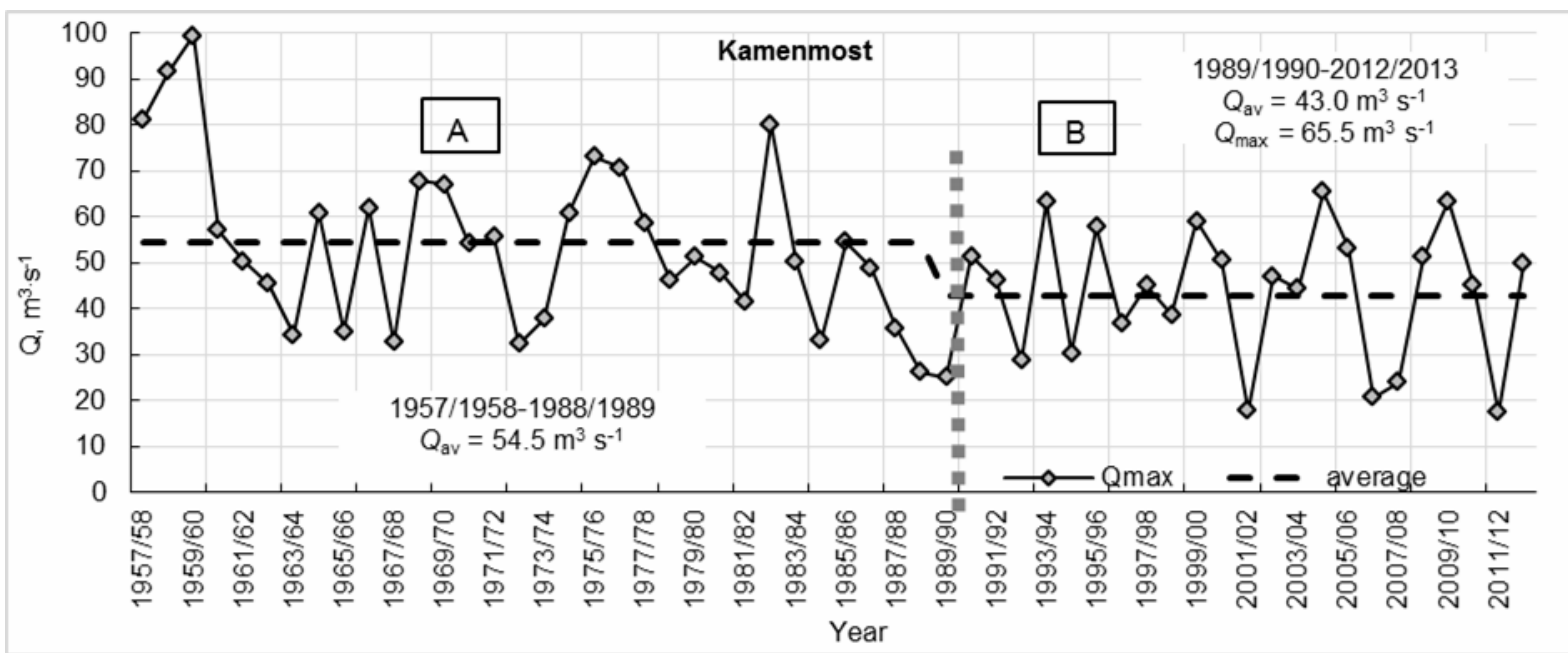

Fig. 7. Series of maximum annual discharges in Kamenmost; A: before reservoir Ricice construction, B: after reservoir construction; source: own study

Table 5. Data for maximum discharges in Kamenmost in different periods

\begin{tabular}{|l|c|c|}
\hline \multicolumn{1}{|c|}{ Parameter } & $1957-1988$ & $1989-2013$ \\
\hline No. of data & 32 & 24 \\
\hline $\begin{array}{l}\text { Mean annual high water discharge, } \\
\mathrm{m}^{3} \cdot \mathrm{s}^{-1}\end{array}$ & 54.5 & 43.0 \\
\hline $\begin{array}{l}\text { Maximum recorded water dis- } \\
\text { charge, } \mathrm{m}^{3} \cdot \mathrm{s}^{-1}\end{array}$ & 99.4 & 65.5 \\
\hline$Q_{\max }$ date & Dec 1959 & Dec 2004 \\
\hline Variance & 320.9 & 220.9 \\
\hline Skewness & 0.65 & -0.33 \\
\hline
\end{tabular}

Explanation: $Q_{\max }=$ maximum recorded water discharge. Source: own study.
Special attention in this work was paid to analyse the effect of precipitation on floods. Therefore, precipitation data were taken from the nearest meteorological station Imotski for the period 1957-2013. The Mann-Kendall test [ZHANG et al. 2014] showed significantly decreasing precipitation on annual scale (about $-3 \mathrm{~mm}$ per year) and decreasing monthly maxima (about $-1.4 \mathrm{~mm}$ per year, Fig. 8). Fig. 8 shows the relationship between monthly maximum precipitation and corresponding maximum discharge (the Vrljika, station Kamenmost) registered in the same month. There was a weak correlation between precipi-

Table 6. Statistical test for Kamenmost: the influence of Ricice reservoir

\begin{tabular}{|c|c|c|c|c|c|c|c|c|c|c|}
\hline \multicolumn{3}{|c|}{ Location: Nuga } & \multicolumn{8}{|c|}{ Parameter: Discharge } \\
\hline \multirow{2}{*}{ No. } & \multirow{2}{*}{ period } & \multirow{2}{*}{$N_{i}$} & \multirow{2}{*}{$\underset{\mathrm{m}^{3} \cdot \mathrm{s}^{-1}}{Q_{\mathrm{av}}}$} & \multirow{2}{*}{$s^{2}$} & \multicolumn{2}{|c|}{$Q \alpha=0.05$} & \multirow{2}{*}{ hypothesis } & \multicolumn{2}{|c|}{$\sigma^{2} \quad \alpha=0.05$} & \multirow{2}{*}{ hypothesis } \\
\hline & & & & & $t$-test & $t_{\text {crit }}$ & & $F$-test & $F_{\text {crit }}$ & \\
\hline 1 & 1957/1958-1988/1989 & 32 & 54.5 & 320 & \multirow{2}{*}{1.90} & \multirow{2}{*}{2.01} & \multirow{2}{*}{$H_{0}$} & \multirow{2}{*}{1.45} & \multirow{2}{*}{1.96} & \multirow{2}{*}{$H_{0}$} \\
\hline 2 & $1989 / 1990-2012 / 2013$ & 24 & 43.0 & 220 & & & & & & \\
\hline
\end{tabular}

Explanations: $N_{i}=$ No. of data, $Q_{\mathrm{av}}=$ mean high water discharge, $s^{2}=$ high water discharge variance. Source: own study.

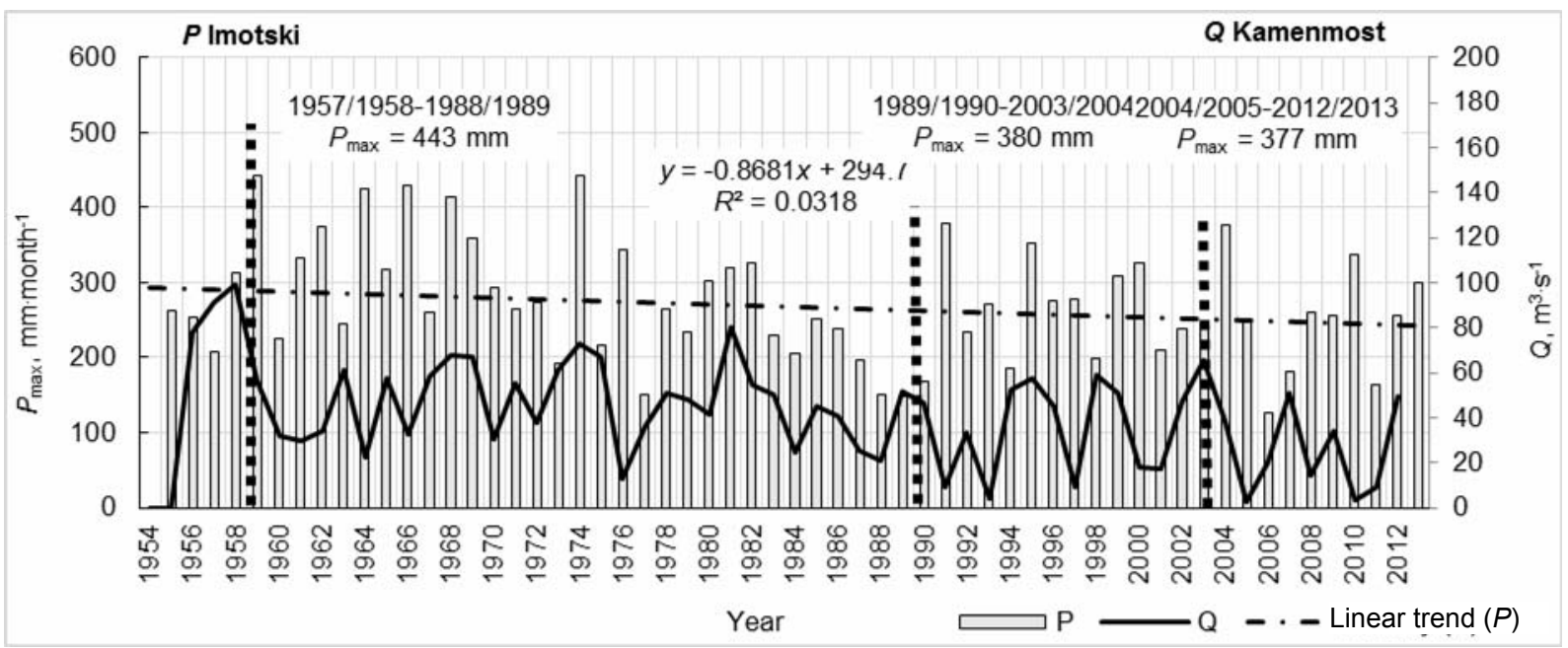

Fig. 8. Series of maximum monthly precipitations $P_{\max }$ with corresponding maximum discharges $Q$; source: own study 

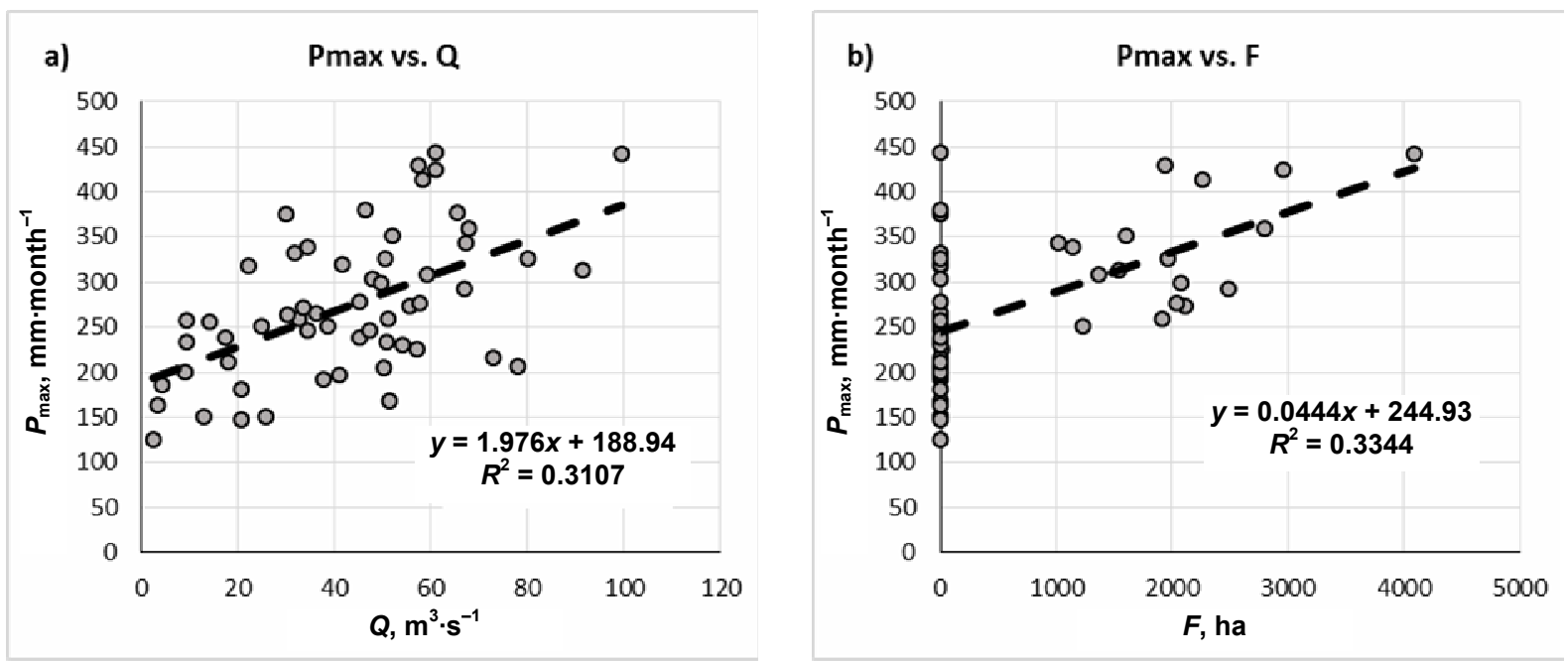

Fig. 9. Correlation between maximum monthly precipitations $P_{\max }$ and corresponding discharges $Q$ (a) and flooded area $F(\mathrm{~b})$; source: own study

tation and flow in the $\operatorname{Vrljika}(Q)$ and between precipitation and respective flooded area $(F)$ (Fig. 9). For example, the maximum monthly precipitation (443 $\mathrm{mm})$ registered in December 1959 generated the maximum surface flow $\left(99.4 \mathrm{~m}^{3} \cdot \mathrm{s}^{-1}\right)$ in the polje and maximum flood (4 097 ha). But the same monthly precipitation in October 1974 (443 mm) generated surface flow of $60.9 \mathrm{~m}^{3} \cdot \mathrm{s}^{-1}$ without flood. These relationships illustrate the natural complexity of karst environment [BONACCI et al. 2013], even if based on monthly scale as in this work.

In comparison to the research of ZHANG et al. [2014], streamflows and floods in Imotsko-Bekijsko Polje are largely influenced by water management objects (reservoirs, retention, tunnel) and only indirectly by precipitation.

\section{CONCLUSION}

Since the middle of the 20th century, numerous facilities have been constructed for water use and flood control in the Imotsko-Bekijsko Polje, including Ricina catchment, from where water comes to the polje by surface and underground flow. Past activities significantly improved the situation, through increasing the safety from flood, decreasing damage to agriculture and water management, and providing a considerable reserve of water for water supply and irrigation.

Obviously, the most important object for flood control is the tunnel Petnjik and then Ricica reservoir. However, the tunnel Petnjik has an influence on the lowest part of the polje, which is most vulnerable in the present conditions. The comparison of different water waves (Fig. 6) shows that flood control in the Imotsko-Bekijsko Polje has been increased due to human activity. The Ricice reservoir and Prolosko blato retention reservoir do not affect the floods of lower area (Nuga), but they have an impact on the flood control in the middle and upper part of the polje by reducing water peaks and decreasing risk of water spreading from the Vrljika riverbed.

Despite previous engineering engagement, agricultural land in the south-eastern lowest part of the polje is still subject to occasional flooding in the winter months. The Petnjik tunnel has sufficient capacity for high water evacuation. But occasionally it has to be closed completely or partially because of downstream runoff conditions, which is the crucial problem for flood control. The solution of this problem requires engagement of institutions and experts from the two countries, Croatia and $\mathrm{B} \& \mathrm{H}$, because it is a border area.

\section{REFERENCES}

BONACCI O. 1987. Karst hydrology: With special references to the Dinaric karst. Berlin. Springer Verl. ISBN 3540181059 pp. 184.

BonACCI O. 2004. Poljes. In: Encyclopedia of caves and karst science. Ed. J. Gunn. New York. Fitzroy Degrborn p. $559-600$

BonACCI O., LJUBENKOV I. 2006. Karst flash floods: an example from the Dinaric karst (Croatia). Natural Hazards and Earth System Science. Vol. 6 p. 195-203.

BonACCI O., ŽElJKOvić I., Galić A. 2013. Karst river's particularities: an example from the Dinaric karst (Croatia/Bosnia and Herzegovina). Environmental Earth Science. Vol. 70 p. 963-974.

KRESIC N. 2013. Water in karst: Management, vulnerability and restoration. New York. McGraw-Hill. ISBN 978071753333 pp. 708.

Minevc A., PrelovŠEK M., HAJNA N.Z. 2010. Introduction to the Dinaric karst. Postojna. Karst Research Institute. ISBN 9789612541989 pp. 71.

Misatović B. 1988. Catastrophic flood in the polje of Cetinje in February 1986, a typical example of the environmental impact of karst. Environmental Geology and Water Sciences. Vol. 12. Iss. 2 p. 117-121.

MiRZA M.M.Q. 2004. The Ganges water diversion: environmental effects and implications. Dordrecht. Kluwer Acad. Publ. ISBN 9789048166657 pp. 367. 
Prohaska S.J. 2003. Hidrologija [Hydrology]. Beograd. Rudarsko-geološkifakultet pp. 428.

RAGHUNATH H.M. 2006. Hydrology: principles, analysis, design. New Delhi. New Age Int. ISBN 8122418252 pp. 476.

SACKL P., Durst R., Kotrošan D., Stumberger B. 2014. Dinaric Karst Poljes - Floods for life. Radolfzell. EuroNatur. ISBN 978-3-00045287-1 pp. 199.
SCHWARZ U. 2013. Flooding analysis of karst poljes in Bosnia \& Herzegovina. Vienna. FLUVIUS pp. 127.

Zhang Q., SingH V.P., Li K., Li J. 2014. Trend, periodicity and abrupt change in streamflow of the East River, the Pearl River basin. Hydrological Processes. Vol. 28. Iss. 2 p. 305-314.

\section{Igor LJUBENKOV}

\section{Ochrona przed powodzią w Dolinie Imotsko-Bekijsko Polje (Chorwacja, Bośnia i Hercegowina)}

\section{STRESZCZENIE}

Słowa kluczowe: Imotsko-Bekijsko Polje, powódź, tereny krasowe, testy statystyczne

Imotsko-Bekijsko Polje ma powierzchnię 9500 ha i jest jedną z największych dolin krasowych w Górach Dynarskich. Teren doliny rozciąga się na terytorium dwóch państw - Chorwacji oraz Bośni i Hercegowiny.

Budowle hydrotechniczne (zbiorniki retencyjne, tunele itp.) zostały zbudowane w połowie XX wieku w celu ochrony doliny przed powodziami. W związku z tym bezpieczeństwo powodziowe znacznie wzrosło, jednak występują jeszcze okresowe powodzie w południowo-wschodniej, najniższej części doliny. Największa powódź w ostatnim czasie zdarzyła się w styczniu 2010 r., zalane zostało wówczas ok. 2676 ha, co stanowi 28\% powierzchni terenu.

Polje jest typowo krasowym terenem o bardzo złożonymi stosunkami hydrologicznymi i hydrogeologicznymi. W niniejszej pracy analizie statystycznej poddano dane z dwóch stacji hydrologicznych - Nuga w najniższej części i Kamenmost w środkowej części doliny. Szczególnie analizowano efektywność istniejących struktur hydrologicznych dla łagodzenia skutków powodzi. Wyniki badań wskazują że powodzie w Imotsko-Bekijsko Polje wywoływane są głównie przez obiekty gospodarki wodnej (zbiorniki retencyjne, tunele itp.) i tylko pośrednio zależą od opadów atmosferycznych. 